2. Sydoruk I. I. Vyznachennia sutnosti poniattia "sotsialna kompetentnist maibutnoho sotsialnoho pratsivnyka. Naukovyi visnyk Uzhhorodskoho universytetu. Seriia: "Pedahohika. Sotsialna robota": zb.nauk. pr. / Red.kol. : Kozubovska I.V. (hol.red.) ta in. Uzhhorod: Vyd-vo UzhNU "Hoverla", 2019. Vypusk 1 (44). 218 s. - S. 174-178.

3. Sydoruk I. I. Teoretychne osmyslennia sutnosti definitsii "kompetentsiia". Pedahohika [Tekst]: zb. nauk. pr.: [materialy Kh Mizhnarodnoi naukovo-praktychnoi kon-ferentsii naukovtsiv, aspirantiv ta studentiv "Aktualni problemy pedahohiky, sotsialnoi roboty ta spetsialnoi svity" (13 travnia 2019 r.)] / za red. P. M. Husaka, A. V. Liakishevoi ta N. I. Korpach. - Lutsk : Vezha-Druk. 2019. 296 s. S. 225-228.

Одержано статтю: 26.09.2019

Прийнято до друку: 16.10.2019

УДК $371.132-021.483$

DOI: $10.15330 /$ esu. 17.278-284
Іванна Таргоній,

аспірантка, Рівненський державний гуманітарний університет (м. Рівне, Україна)

Ivanna Targonii,

Post-graduate student, Rivne State Humanitarian University (Rivne, Ukraine)

ivancal8@ukr.net

\title{
ТОЛЕРАНТНІСТЬ СТУДЕНТІВ ПЕДАГОГІЧНИХ КОЛЕДЖІВ: СТАН ВИХОВАНОСТІ
}

\section{TOLERANCE OF PEDAGOGICAL COLLEGES' STUDENTS: STATE OF EDUCATION}

У статті проаналізовано стан вихованості толерантності у студентів педагогічних коледжів. Розроблено критерії та відповідні показники вихованості толерантності у студентів педагогічних коледжів: когнітивний (знания иодо сутності толерантності; усвідомлення значущості толерантності у суспільстві; знання про якості толерантної особистості); емочійно-иіннісний (розвинена емпатія; мотивація на виявлення якостей толерантної особистості; прагнення до діалогічного спілкування); поведінковий (вміння: виявляти гуманність, терпимість, доброзичливість, чуйність, володіти своїми емочіями та поведінкою; взаємодіяти, співпрацювати та вступати в діалогічне спілкування; знаходити способи попередження та виріиення конфліктів). Здійснено добір діагностичного інструментарію відповідно до проблематики досліджения, вікових особливостей раннього юнацького віку; виявлено та схарактеризовано рівні вихованості толерантності у студентів педагогічних коледжів.

Ключові слова: толерантність, виховання толерантності, критерії $i$ показники вихованості толерантності, стан вихованості толерантності, студенти педагогічних коледжів.

The article analyzes the state(level) of pedagogical colleges' students tolerance. The criteria and corresponding indicators of tolerance education among students of pedagogical colleges are developed: cognitive (knowledge about the essence of tolerance; awareness of the importance of tolerance in society; knowledge about the qualities of a tolerant personality); emotional value (developed empathy; motivation to identify the qualities of a tolerant personality; desire for dialogic communication); behavioral (ability: to show humanity, tolerance, kindness, responsiveness, to possess their emotions and behavior; to interact, cooperate and engage in dialogue; to find ways to prevent and resolve conflicts). The selection of diagnostic tools in accordance with the research issues, age characteristics of early adolescence; levels of education of tolerance of pedagogical colleges students are revealed and characterized. 
Exacerbation of the crisis in modern Ukrainian society has led to the spread of aggression, violence, discrimination, intolerance to people of another culture, different point of view. In such circumstances, the problem of education of students of pedagogical colleges of tolerance as a moral trait of personality, which manifests itself in the value attitude towards other people, regardless of their views, habits, character, race, nationality, social status, religious affiliation, becomes especially relevant.

The criteria and indicators of education of tolerance in students of pedagogical colleges are developed: cognitive (knowledge about the essence of tolerance; awareness of the importance of tolerance in society; knowledge about the qualities of a tolerant personality); emotional and value (developed empathy; motivation to identify the qualities of a tolerant personality; desire for dialogic communication); behavioral (ability: to show humanity, tolerance, kindness, responsiveness, to possess their emotions and behavior; to interact, cooperate and engage in dialogue; to find ways to prevent and resolve conflicts).

Key words: tolerance, education of tolerance, criteria and indicators of education of tolerance, state of education of tolerance, students of pedagogical colleges.

Постановка проблеми у загальному вигляді та ії зв'язок із важливими науковими і практичними завданнями. Загострення кризових явищ в сучасному українському суспільстві призвели до розповсюдження проявів агресивності, насильства, дискримінації, нетерпимості до людей іншої культури, іншої точки зору. За таких обставин особливої актуальності набуває проблема виховання у студентів педагогічних коледжів толерантності як моральної риси особистості, яка виявляється в ціннісному ставленні до інших людей, незалежно від їхніх поглядів, звичок, характеру, раси, національності, соціального стану, релігійної приналежності.

Аналіз останніх досліджень і публікацій, в яких започатковано розв'язання порушеної проблеми i на які спирасться автор. Сучасні вчені-педагоги Ю. Гордієнко [2]; Р. Кострубань [6], Ю. Котелянець [7]; І. Кривошапка [5]; Ю. Тодорцева [8], М. Якібчук [11] та ін. досліджують проблему виховання толерантності у майбутніх учителів.

Водночас, проблема виховання толерантності у студентів педагогічних коледжів у позааудиторній діяльності залишилася поза увагою науковців та не набула всебічного висвітлення.

Мета статті - проаналізувати стан вихованості толерантності у студентів педагогічних коледжів.

Виклад основного матеріалу дослідження 3 повним обгрунтуванням одержаних результатів. Виявлення стану вихованості толерантності у студентів педагогічних коледжів здійснювалося у процесі констатувального етапу експерименту, що включав наступні завдання:

- розробити критерії і показники вихованості толерантності у студентів педагогічних коледжів;

- здійснити добір діагностичного інструментарію відповідно до проблематики дослідження, вікових особливостей раннього юнацького віку;

- провести серії діагностичних процедур;

- виявити рівні вихованості толерантності у студентів педагогічних коледжів.

У процесі дослідження приймали участь 389 студентів педагогічних коледжів.

У педагогічній теорії критерій подається як ознака, на основі якої здійснюється оцінка: “критерій - засіб для судження, ознака, на основі якої робиться оцінка, визначення або класифікація чого-небудь", “мірило судження та оцінки" “основна ознака, за якою одне рішення обирається із багатьох можливих" [3, с. 8]. Таким 
чином, критерій розуміється як деяка найбільш загальна властивість, за якою міркують про те чи інше явище, що об'єднує в собі низку простих показників, що можуть безпосередньо спостерігатися та підлягати вимірюванню.

Розроблено критерії та показники вихованості толерантності у студентів педагогічних коледжів: когнітивний (знання щодо сутності толерантності; усвідомлення значущості толерантності в суспільстві; знання про якості толерантної особистості); емоційно-цінннісний (розвинена емпатія; мотивація на виявлення якостей толерантної особистості; прагнення до діалогічного спілкування); поведінковий (вміння: виявляти гуманність, терпимість, доброзичливість, чуйність, володіти своїми емоціями та поведінкою; взаємодіяти, співпрацювати та вступати в діалогічне спілкування; знаходити способи попередження та вирішення конфліктів).

Важливою умовою відбору методів педагогічної діагностики наявного рівня вихованості толерантності у студентів педагогічних коледжів була здатність педагогів із максимальною об’єктивністю зібрати інформацію, здійснити іiі грунтовний аналіз. В основу роботи було покладено вимоги щодо інформації, яку було одержано за допомогою різноманітних методів педагогічної діагностики. Ця інформація відзначалася:

- адекватністю - однозначним відображенням стану об'єкта, що діагностується;

- об'єктивністю - відсутністю суб'єктивних чинників під час збирання та опрацювання інформації до тієї міри, яка можлива в певній ситуації. Найчастіше об'єктивність встановлювалася шляхом повторного (додаткового) збирання інформації або паралельного іiі фіксування незалежними спостерігачами (педагогами);

- достатністю - інформація повною мірою задовольняла умови і завдання щодо визначення стану об'єкта, який діагностується [4, с. 73].

Під час дослідження було використано комплекс діагностичних методів і методик, а саме: написання та аналіз студентських творів, бесіди, метод незакінчених речень, тест "Ваші емпатійні здібності" (В. Бойко) [10], методика діагностики спрямованості особистості (Б. Басса) [1], методика діагностики доброзичливості за шкалою Кемпбелла [1], методика діагносткти вольового потенціалу особистості (Н. Фетискіна, В. Козлова, Г. Мануйлова) [9], методика вивчення рівнів сформованості комунікативних та організаційних здібностей (Н. Фетискіна, В. Козлова, Г. Мануйлова) [9], методика "Експрес-діагностики поведінкового стилю в конфліктній ситуації (Н. Фетискіна, В. Козлова, Г. Мануйлова) [9], педагогічне спостереження.

Проаналізуємо результати діагностики рівня вихованості толерантності у студентів педагогічних коледжів за когнітивним критерієм (знання щодо сутності толерантності; усвідомлення значущості толерантності в суспільстві; знання про якості толерантної особистості).

3 метою визначення рівня вихованості толерантності за показниками: "знання щодо сутності толерантності”, “усвідомлення значущості толерантності в суспільстві” використовували такі методи, як написання творів на тему “Що значить бути толерантною особистістю?", бесіди.

План твору не давався. Під час написання твору студенти мали виявляти щирість та самостійність.

Визначення рівня вихованості толерантності за показником "знання про якості толерантної особистості" відбувалося за допомогою застосування методики незакінчених речень. Студентам було запропоновано доповнити незакінчені речення: “Толерантну людину характеризують такі якості ....”, “Гуманна людина - це та, яка 
..”, “Доброзичлива людина - це та, яка ...”; “Бути чуйною людиною - це ....”, “Бути терпимою людиною - це ....”, “Виявляти самовладання - це ...”.

Аналіз результатів дослідження за когнітивним критерієм свідчить, що 30,3 \% студентів педагогічних коледжів виявили низький рівень вихованості толерантності; 34,3 \% студентів виявили середній рівень; високий рівень вихованості толерантності за даним критерієм виявило $35,4 \%$ студентів.

Проаналізуємо результати констатувального етапу експерименту шодо рівня вихованості толерантності у студентів педагогічних коледжів за емоційно-ціннісним критерієм (розвинена емпатія; мотивація на виявлення якостей толерантної особистості; прагнення до діалогічного спілкування).

3 метою вирішення цього завдання було використано: тест "Ваші емпатійні здібності” (В. Бойко) [10], методика діагностики спрямованості особистості (Б. Басса) [1], опосередковані педагогічні спостереження.

Вивчення рівня вихованості толерантності у студентів педагогічних коледжів за показником "розвинена емпатія" відбувалося за допомогою тесту "Ваші емпатійні здібності” (В. Бойко) [10]. Результати дослідження дозволяють констатувати, що $23,1 \%$ студентів педагогічних коледжів виявили високий рівень розвитку емпатії; $29,6 \%$ студентів - середній рівень розвитку емпатії. 47,3\% - низький рівень розвитку емпатії.

Діагностика рівня вихованості толерантності у студентів педагогічних коледжів за показником "мотивація на виявлення якостей толерантної особистості" здійснювалася за допомогою методики діагностики спрямованості особистості (Б. Басса) [1].

Слід зазначити, що 23,2\% студентів виявили альтруїстичні мотиви; 43,7\% студентів - егоїстичні мотиви; 33,1 \% студентів - прагматичні мотиви.

Вивчення рівня вихованості толерантності у студентів педагогічних коледжів за показником “прагнення до діалогічного спілкування" здійснювалося за допомогою використання картки педагогічних спостережень.

Результати дослідження свідчать, що 40,7\% учасників експерименту не виявляють прагнення до діалогічного спілкування; $32,6 \%$ респондентів виявили ситуативне прагнення до діалогічного спілкування; 26,7\% респондентів виявили стійке прагнення до діалогічного спілкування.

Як свідчать дані дослідження, 24,3\% студентів педагогічних коледжів виявили високий рівень вихованості толерантності за емоційно-ціннісним критерієм; середній рівень - 31,8 \% студентів; низький рівень - 43,9\% студентів.

Діагностика рівня вихованості толерантності у студентів педагогічних коледжів за поведінковим критерієм (вміння: виявляти гуманність, терпимість, доброзичливість, чуйність, володіти емоціями і поведінкою; взаємодіяти, співпрацювати та вступати в діалогічне спілкування; знаходити способи попередження та вирішення конфліктів) відбувалося за допомогою таких методів і методів, як-от: методика діагностики доброзичливості (за шкалою Кемпбелла) [1], методика діагностики вольового потенціалу особистості (Н. Фетискіна, В. Козлова, Г. Мануйлова) [9], методика вивчення рівня сформованості комунікативних та організаційних здібностей (Н. Фетискіна, В. Козлова, Г. Мануйлова) [9], методика "Експрес-діагностика поведінкового стилю у конфліктній ситуаціі” [9], опосередковане педагогічне спостереження.

Отримані дані за допомогою використання методики діагностика (за шкалою Кемпбелла) [1] дозволяють стверджувати, що 28,5\% учасників експерименту 
виявили високий показник доброзичливого ставлення до інших; 37,0 \% респондентів - середній показник; 34,5\% респондентів - низький показник доброзичливого ставлення до інших.

Використовуючи методику діагностики вольового потенціалу особистості (Н. Фетискіна, В. Козлова, Г. Мануйлова) [9] отримали наступні дані: високу силу волі виявило 30,3\% учасників експерименту; середню силу волі - 36,3\% респондентів; низьку силу волі - 33,4 \% респондентів.

3 метою визначення рівня вихованості толерантності у студентів педагогічних коледжів за показником “вміння виявляти гуманність, терпимість, доброзичливість, володіти своїми емоціями і поведінкою” використовували картку педагогічних спостережень.

Як свідчать результати дослідження, 29,3 \% студентів педагогічних коледжів виявляють гуманність, терпимість, доброзичливість, чуйність, вміють контролювати власні емоції та поведінку; 34,1 \% здобувачів вищої освіти намагаються виявляти гуманність, терпимість, доброзичливість, чуйність, намагаються контролювати власну поведінку; 46,6 \% студентів педагогічних коледжів виявляють нетерпимість, агресивність, нестриманість, не вміють контролювати власну поведінку.

Вивчення рівня вихованості толерантності у студентів педагогічних коледжів за показником “вміння взаємодіяти, співпрацювати та вступати в діалогічне спілкування” відбувалося за допомогою використання адаптованої методики вивчення рівня сформованості комунікативних та організаторських здібностей (Н. Фетискіна, В. Козлова, Г. Мануйлова) [9], картки педагогічних спостережень.

Результати дослідження дозволяють констатувати, що 40,6 \% учасників експерименту не виявляють вміння взаємодіяти, співпрацювати, виявляють нестриманість, відрізняються хибним уявленням про власну виключність; не виявляють бажання вступати в діалог; 34,2\% респондентів намагаються співпрацювати та вступати в діалогічне спілкування; 25,2\% респондентів виявляють вміння співпрацювати та вступати в діалогічне спілкування.

3 метою визначення рівня вихованості толерантності у студентів педагогічних коледжів за показником “вміння знаходити способи попередження та вирішення конфліктів" використовували методику діагностики поведінкового стилю у конфліктній ситуації (Н. Фетискіна, В. Козлова, Г. Мануйлова) [9].

Варто зазначити, що 42,9\% студентів використовують жорсткий стиль щодо вирішення конфліктних ситуацій, оскільки у будь-якому випадку до кінця захищають свою позицію, наполягають на своєму, вважають себе завжди правими.

Зауважимо, що 33,6 \% учасників експерименту 3 готовністю погоджуються 3 точкою зору противника, відмовляються від своєї.

Компромісний стиль вирішення конфліктів є характерним для 23,5\% респондентів, які під час вирішення конфлікту намагаються запропонувати рішення, яке б задовольнило обидві сторони.

За результатами проведеного дослідження констатуємо, що 26,0 \% студентів педагогічних коледжів виявили високий рівень вихованості толерантності за поведінковим критерієм; 34,8 \% студентів - середній рівень; 39,2 \% студентів низький рівень.

3 огляду на результати діагностики, відповідно до означених критеріїв і показників було визначено три рівні вихованості толерантності у студентів педагогічних коледжів: високий, середній, низький. 
Високий рівень. Студенти педагогічних коледжів мають грунтовні знання про сутність толерантності, усвідомлюють значущість толерантності в суспільстві; виявляють глибокі знання про якості толерантної особистості; характеризуються розвиненою емпатією; мотивацією на виявлення якостей толерантної особистості; виявляють прагнення до діалогічного спілкування; гуманність, терпимість, доброзичливість, чуйність, володіють власними емоціями і поведінкою; вміють співпрацювати та вступати в діалогічне спілкування; знаходити способи попередження та вирішення конфліктів. Кількість таких студентів становила 26,9\%.

Середній рівень. Студенти педагогічних коледжів мають достатні знання щодо сутності толерантності; усвідомлюють значущість толерантності в суспільстві; мають достатні знання про якості толерантної особистості; виявляють середній рівень розвитку емпатії; недостатньо сформовану мотивацію на виявлення якостей толерантної особистості; намагаються виявляти гуманність, терпимість, доброзичливість, чуйність; не завжди спроможні контролювати вияв негативних емоцій; намагаються співпрацювати та вступати в діалогічне спілкування; не завжди вміють знаходити способи попередження та вирішення конфліктів. Серед досліджених студентів педагогічних коледжів таких було виявлено 33,6 \%.

Низький рівень. Студенти мають фрагментарні знання про сутність толерантності; не усвідомлюють значущість толерантності в суспільстві; виявляють фрагментарні знання щодо якостей толерантної особистості; характеризуються низьким рівнем розвитку емпатії; відсутністю мотивації на виявлення якостей толерантної особистості; виявляють нетерпимість, агресивність, не співчувають і не вболівають за іншого; не контролюють власну поведінку; характеризуються відсутністю прагнення конструктивно вирішувати конфлікти. Кількість таких студентів 39,5\%.

Висновки представленого у статті дослідження і перспективи подальших наукових розвідок із зазначеного напряму. Результати констатувального етапу експерименту засвідчили, що більшість студентів педагогічних коледжів виявили низький рівень вихованості толерантності - 39,5\%; середній рівень вихованості толерантності - 33,6\% студентів; високий рівень - 26,9\% студентів педагогічних коледжів.

Аналіз і узагальнення результатів дослідження засвідчили необхідність посилення уваги до теоретичного обгрунтування та експериментальної перевірки педагогічних умов виховання толерантності у студентів педагогічних коледжів у позааудиторній діяльності.

Установлено, що куратори студентських груп відчувають значні труднощі щодо вибору ефективних форм і методів виховання толерантності у студентів педагогічних коледжів; можливості позааудиторної діяльності використовуються недостатньо.

Проведене дослідження не вичерпує всіх науково-дослідницьких аспектів означеної проблеми. Подальшого вивчення потребують такі питання: підвищення ефективності післядипломної освіти педагогічних кадрів 3 проблеми виховання толерантності у студентів педагогічних коледжів; використання потенціалу позааудиторної діяльності у контексті досліджуваної проблеми.

\section{Література}

1. Горбатов Д. Практикум по психологическому исследованию: учебное пособие. Самара: БАХРАХ. Москва 2008. 270 с.

2. Гордієнко Ю. А. Формування педагогічної толерантності майбутніх учителів іноземних мов початкової школи : автореф. дис. ... канд. пед. наук : спец. 13.00.04. Теорія і методика професійної освіти. Київ, 2017. 20 с. 
3. Звєрєва І. Д. Діагностика моральної вихованості школярів / І. Д. Звєрєва, Л. Г. Коваль, П. Д. Фролов. Київ : ІСДО, 1995. 156 с.

4. Кравченко Т. В. Соціалізація дітей шкільного віку у взаємодії сім'ї і школи: монографія. Київ : Фенікс, 2009. 416 с.

5. Кривошапка I. В. Виховання толерантності майбутніх викладачів вищої школи в умовах магістратури : автореф. дис. ... канд. пед. наук : спец. 13.00.04 Теорія і методика професійної освіти. Київ, 2017. 20 с.

6. Кострубань Р. В. Формування толерантності у майбутніх учителів у процесі гуманітарної підготовки у педагогічних коледжах: автореф. дис. ... канд. пед. наук : спец. 13.00.04 Теорія і методика професійної освіти. Хмельницький, 2016. 20 с.

7. Котелянець. Ю. С. Формування толерантності майбутніх учителів початкових класів у процесі професійної діяльності : автореф. дис. ... канд. пед. наук : спец. 13.00.04. Теорія і методика професійної освіти. Кіровоград, 2015. 20 с.

8. Тодорцева Ю. В. Формування толерантності майбутніх учителів у процесі професійної підготовки: автореф. дис. ... канд. пед. наук : спец. 13.00.04. Теорія і методика професійної освіти. Одеса, 2004. 42 с.

9. Фетискин Н. П. Социально-психологическая диагностика развития личности и малых групп / Н. П. Фетискин, В. В. Козлов, Г. М. Мануйлов. Москва : Изд-во Института психотерапии, 2002. $490 \mathrm{c}$

10. Шеламова Г. М. Педагогические условия формирования толерантности учащихся профессионального лицея: дисс... канд. пед. наук : спец. 13.00.01 Общая педагогика и история педагогики. Москва, 2003. 180 с.

11. Якібчук M. I. Формування толерантності у студентів вищих педагогічних закладів: монографія. Київ : Компринт, 2018. 271 с.

\section{References}

1. Gorbatov D. Praktikum po psihologicheskomu issledovaniyu: uchebnoe posobie. Samara: BAHRAH. Moskva 2008. $270 \mathrm{~s}$.

2. Hordiienko Yu. A. Formuvannia pedahohichnoi tolerantnosti maibutnikh uchyteliv inozemnykh mov pochatkovoi shkoly : avtoref. dys. ... kand. ped. nauk : spets. 13.00.04 "Teoriia i metodyka profesiinoi osvity". Kyiv, 2017.20 s.

3. Zvierieva I. D. Diahnostyka moralnoi vykhovanosti shkoliariv / I. D. Zvierieva, L. H. Koval, P. D. Frolov. Kyiv : ISDO, 1995. $156 \mathrm{~s}$.

4. Kravchenko T. V. Sotsializatsiia ditei shkilnoho viku u vzaiemodii simi i shkoly: monohrafiia. Kyiv : Feniks, 2009. $416 \mathrm{~s}$.

5. Kryvoshapka I. V. Vykhovannia tolerantnosti maibutnikh vykladachiv vyshchoi shkoly v umovakh mahistratury : avtoref. dys. ... kand. ped. nauk : spets. 13.00.04 "Teoriia i metodyka profesiinoi osvity". Kyiv, 2017.20 s.

6. Kostruban R. V. Formuvannia tolerantnosti u maibutnikh uchyteliv u protsesi humanitarnoi pidhotovky u pedahohichnykh koledzhakh: avtoref. dys. ... kand. ped. nauk : spets. 13.00.04 "Teoriia i metodyka profesiinoi osvity". Khmelnytskyi, 2016. 20 s.

7. Kotelianets. Yu. S. Formuvannia tolerantnosti maibutnikh uchyteliv pochatkovykh klasiv u protsesi profesiinoi diialnosti : avtoref. dys. ... kand. ped. nauk : spets. 13.00.04 "Teoriia i metodyka profesiinoi osvity". Kirovohrad, 2015.20 s.

8. Todortseva $\mathrm{Yu}$. V. Formuvannia tolerantnosti maibutnikh uchyteliv u protsesi profesiinoi pidhotovky: avtoref. dys. ... kand. ped. nauk : spets. 13.00.04. "Teoriia i metodyka profesiinoi osvity". Odesa, 2004. $42 \mathrm{~s}$

9. Fetiskin N. P. Socialno-psihologicheskaya diagnostika razvitiya lichnosti i malyh grupp / N. P. Fetiskin, V. V. Kozlov, G. M. Manujlov. Moskva : Izd-vo Instituta psihoterapii. 2002. $490 \mathrm{~s}$.

10. Shelamova G. M. Pedagogicheskie usloviya formirovaniya tolerantnosti uchashihsya professionalnogo liceya: diss ... kand. ped. Nauk : spec. 13.00.01 "Obshaya pedagogika i istoriya pedagogiki". Moskva, 2003. $180 \mathrm{~s}$.

11. Yakibchuk M. I. Formuvannia tolerantnosti u studentiv vyshchykh pedahohichnykh zakladiv : Monohrafiia. Kyiv : Komprynt, 2018. $271 \mathrm{~s}$. 